\title{
Association Between Plasma Beta-2 Microglobulin Level and Cardiac Performance in Patients With Chronic Kidney Disease
}

\author{
Omid Sedighi ${ }^{1}$; Saeid Abediankenari ${ }^{1,2,}$; Batoul Omranifar ${ }^{3}$ \\ ${ }_{1}^{1}$ Immunogenetic Research Center, Imam Khomeini Hospital, Mazandaran University of Medical Sciences, Sari, IR Iran \\ ${ }^{2}$ Diabetes Research Center, Mazandaran University of Medical Sciences, Sari, IR Iran \\ 3 Department of Cardiology, Imam Khomeini Hospital, Mazandaran University of Medical Sciences, Sari, IR Iran \\ ${ }^{*}$ Corresponding author: Saeid Abediankenari, Diabetes Research Center, Mazandaran University of Medical Sciences, Sari, IR Iran. Tel: +98-9121985667, Fax: +98-1513543087, E-mail:
} abedianlab@yahoo.co.uk

Received: September 11, 2014; Accepted: October 1, 2014

\begin{abstract}
Background: Beta-2 microglobulin(B2M) is considered as a surrogate marker for middle molecule uremic toxins and a key component in dialysis-related amyloidosis. However, few studies have evaluated role of B2M in patients with chronic kidney disease (CKD).

Objectives: The purpose of this study was to evaluate the association of plasma B2M level with some metabolic and cardiac performance factors in patients with CKD.

Patients and Methods: In this case-control study, we measured plasma B2M level in 86 patients with different stages of CKD and 78 ageand sex-matched individuals, as healthy control group. Then we investigated the association between plasma B2M level and left ventricular hypertrophy, ejection fraction (EF), and left ventricular end-diastolic diameter (LVEDD) in echocardiography and some inflammatory and metabolic factors in patients with CKD.

Results: Mean plasma B2M level was significantly higher in patients with CKD than in control group $(\mathrm{P}<0.001)$. It was directly correlated with serum C-reactive protein $(r=0.167, P<0.001)$, phosphate $(r=0.112, P<0.001)$ levels, and left ventricular $\operatorname{mass}$ index $(r=0.438, P<0.001)$ and $\operatorname{LVEDD}(\mathrm{r}=0.275, \mathrm{P}<0.001)$ in echocardiography. It was also inversely correlated with glomerular filtration $\operatorname{rate}(\mathrm{r}=-0.033, \mathrm{P}<0.001)$, $\operatorname{albumin}(\mathrm{r}=-0.521, \mathrm{P}<0.001)$, hemoglobin $(\mathrm{r}=-0.748, \mathrm{P}<0.001)$, and $\mathrm{EF}(\mathrm{r}=-0.625, \mathrm{P}<0.001)$.

Conclusions: Our findings suggested that plasma B2M level is inversely associated with GFR and EF and directly correlated with some metabolic and cardiac performance factors.

Keywords:Chronic Kidney Disease; Cardiovascular Disease
\end{abstract}

\section{Background}

Beta-2 microglobulin (B2M) is a low-molecular-weight polypeptide (11800 Da), which is present on the surface of all nucleated cells, expressing the major histocompatibility class I (1). Under physiologic conditions, B2M is produced at a constant rate and is eliminated from circulation by kidneys. In patients with a range of inflammatory, hematologic, immunodeficiency, and renal diseases, plasma B2M levels are elevated (2).

In patients with chronic kidney disease (CKD), plasma B2M levels are elevated, especially in patients on hemodialysis (HD) in whom glomerular filtration rate (GFR) is almost completely absent (3). B2M is also a surrogate marker of middle-molecular-weight uremic toxins in patients on HD, which is cleared only by high-flux membrane (4). In some studies, predialysis serum B2M level predicted mortality and increase of B2M clearance during HD was associated with improved outcomes $(5,6)$. In addition, elevated plasma B2M level is a potential risk factor for the development of dialysis-related amyloidosis (7).

It is still unclear whether B2M is an important factor of cardiovascular mortality in patients with CKD (8). In some clinical studies, B2M had an active role in vascular damage by up regulation of interleukin-1 (IL-1) and tumor necrosis factor $\alpha$ (TNF- $\alpha$ ) expression (9). In addition, it might cause cardiovascular disease by amyloid formation (10). However, in the other studies, higher serum B2M levels were associated with better nutritional status and survival in patients with CKD (11).

\section{Objectives}

The aim of this study was to determine the association of plasma B2M level with other serum inflammatory and nutritional markers and cardiac performance factors (systolic and diastolic function) in patients with CKD.

\section{Patients and Methods}

In this case-control study conducted in a nephrology clinic in Sari City, North of Iran, from February 2013 to April 2014, the participation of patients was voluntary and based on the invitation. Case group included 86 patients with different stages of CKD (estimated creatinine 
clearances $<90 \mathrm{~mL} / \mathrm{min} / 1.73 \mathrm{~m}^{2}\left[<1.50 \mathrm{~mL} / \mathrm{s} / \mathrm{m}^{2}\right]$, calculated by Cockcroft and Gault formula, with duration of at least three months) and age of 30 to 70 years. Patients with stage $\mathrm{V}$ of CKD (estimated creatinine clearance $<15$ $\left.\mathrm{mL} / \mathrm{min} / 1.73 \mathrm{~m}^{2}\left[<0.25 \mathrm{~mL} / \mathrm{s} / \mathrm{m}^{2}\right]\right)$, presence of atrial fibrillation, complete heart block, and chronic inflammatory diseases, history of HD or kidney transplantation, and acute cardiovascular events in the preceding three months were excluded. This group of patients was compared with 78 age- and sex-matched healthy persons, as control group. The study protocol was approved by the local Ethics Committee and all patients signed an informed consent form.

\subsection{Laboratory Tests}

Fasting blood samples were collected from both case and control groups. After separation of serum from blood samples, the specimens were immediately transferred to the laboratory. Serum creatinine, blood urea nitrogen, total cholesterol, triglyceride, high density lipoprotein, low density lipoprotein, calcium, phosphorous, albumin, hemoglobin (Hb), C-reactive protein (CRP), and erythrocyte sedimentation rate were assayed by Pars Azmoon laboratory kits (Karaj, Iran), using an auto-analyzer (Prestige 24i, Japan). The plasma B2M concentration was measured by nephelometry method in basis of standard kit (Binding site, UK). Body mass index (BMI) was calculated by dividing body weight to square of height.

\subsection{Echocardiography}

Echocardiography measurements including two dimensionally guided M-mode echocardiograms (Vivid, USA, 2010) of the left ventricle were performed within two hours after blood sampling by a cardiologist unaware of the biochemical findings, according to recommendations of the American Society of Echocardiography (12). Left ventricular mass was calculated by Devereux and Reicheck formula (13) and indexed to body surface area to obtain left ventricular mass index (LVMI). Left ventricular hypertrophy $(\mathrm{LVH})$ was defined as a LVMI $>115 \mathrm{~g} / \mathrm{m}^{2}$ in men $>94 \mathrm{~g} / \mathrm{m}^{2}$ in women (14).

\subsection{Statistical Analysis}

All date were analyzed by SPSS 17.0 (SPSS Inc. Chicago, IL, USA). Continuous variables were shown as the mean \pm standard deviation. We compared qualitative and quantitative parameters between groups by Chi square test and independent-samples t test, respectively. We also used Pearson's correlation test to evaluate the association between variables. P values $<0.05$ were considered as statistically significant.

\section{Results}

Table 1 illustrates the baseline clinical characteristics of patients with CKD (group I; $\mathrm{n}=86$ ) and healthy control subjects (group $\Pi ; n=78$ ). Mean age of patients with CKD and controls were $62.17 \pm 16.52$ and $58.61 \pm 9.62$ years, respectively. There were no significant differences regarding age, sex, and BMI between two groups. Mean plasma B2M level was significantly higher in patients with CKD than control group $(\mathrm{P}<0.001)$. Table 2 shows echocardiography data of the study population. Table 3 shows the correlation between plasma B2M level and other clinical, biochemical, and echocardiographic profiles in patients with CKD.

Plasma B2M level was significantly and directly correlated with serum creatinine $(\mathrm{r}=0.536, \mathrm{P}<0.001)$, CRP $(\mathrm{r}=0.167, \mathrm{P}<0.001)$, and phosphate levels $(\mathrm{r}=0.112, \mathrm{P}<$ $0.001)$. It was also directly correlated with $\operatorname{LVMI}(\mathrm{r}=0.438$, $\mathrm{P}<0.001)$, interventricular septal thickness $(\mathrm{r}=0.321, \mathrm{P}$ $=0.002)$, left ventricular end diastolic diameter (LVEDD) $(r=0.275, P=0.006)$, and left ventricular end systolic diameter (LVESD) $(\mathrm{r}=0.155, \mathrm{P}=0.023)$. It was significantly and inversely correlated with GFR $(\mathrm{r}=-0.033, \mathrm{P}<0.001)$, albumin $(\mathrm{r}=-0.521, \mathrm{P}<0.001), \mathrm{Hb}(\mathrm{r}=-0.748, \mathrm{P}<0.001)$, and ejection fraction $(\mathrm{r}=-0.625, \mathrm{P}<0.001)$.

Table 1. Clinical and Biochemical Characteristics of the Study Population ${ }^{\mathrm{a}, \mathrm{b}}$

\begin{tabular}{|c|c|c|c|}
\hline Parameter & $\begin{array}{l}\text { Group I } \\
(\mathbf{n}=\mathbf{8 6})\end{array}$ & $\begin{array}{l}\text { Group II } \\
(n=78)\end{array}$ & P Value \\
\hline Age, $y$ & $62.17 \pm 16.52$ & $58.61 \pm 9.62$ & 0.114 \\
\hline Gender & & & 0.732 \\
\hline Male & 46 & 41 & \\
\hline Female & 40 & 37 & \\
\hline BMI, $\mathbf{k g} / \mathrm{m}^{2}$ & $22.14 \pm 3.66$ & $24.72 \pm 6.18$ & 0.641 \\
\hline Serum Cr, $\mu \mathrm{mol} / \mathrm{L}$ & $195.36 \pm 68.95$ & $76.02 \pm 18.56$ & $<0.001$ \\
\hline GFR, $\mathrm{mL} / \mathrm{min}$ & $48.2 \pm 17.3$ & $102.8 \pm 31.6$ & $<0.001$ \\
\hline Hemoglobin, $\mathrm{g} / \mathrm{L}$ & $112 \pm 23.2$ & $142 \pm 35.2$ & 0.002 \\
\hline $\begin{array}{l}\text { Serum Calcium, } \\
\mathrm{mmol} / \mathrm{L}\end{array}$ & $2.29 \pm 0.58$ & $2.43 \pm 1.10$ & 0.173 \\
\hline $\begin{array}{l}\text { Serum Phosphate, } \\
\text { mmol/L }\end{array}$ & $1.52 \pm 0.39$ & $1.39 \pm 0.84$ & 0.165 \\
\hline Albumin, $\mathrm{g} / \mathrm{L}$ & $31.8 \pm 6.6$ & $47.7 \pm 12.3$ & 0.012 \\
\hline $\begin{array}{l}\text { C-Reactive Protein, } \\
\text { nmol/dL }\end{array}$ & $64.76 \pm 43.81$ & $29.52 \pm 24.76$ & 0.002 \\
\hline $\begin{array}{l}\text { Total Cholesterol, } \\
\text { mmol/L }\end{array}$ & $5.99 \pm 1.10$ & $5.66 \pm 1.86$ & 0.621 \\
\hline $\begin{array}{l}\text { LDL-Cholesterol, } \\
\text { mmol/L }\end{array}$ & $3.49 \pm 0.84$ & $3.14 \pm 0.21$ & 0.452 \\
\hline Triglycerides, $\mathrm{mmol} / \mathrm{L}$ & $2.68 \pm 0.50$ & $2.54 \pm 0.35$ & 0.663 \\
\hline $\begin{array}{l}\text { Beta-2 Microglobulin, } \\
\mathrm{mg} / \mathrm{L}\end{array}$ & $7.6 \pm 3.7$ & $2.1 \pm 1.7$ & $<0.001$ \\
\hline
\end{tabular}


Table 2. Echocardiographic Data of the Study Population a,b

\begin{tabular}{|c|c|c|c|}
\hline Parameter & $\begin{array}{l}\text { Group I } \\
(\mathbf{n}=\mathbf{8 6}) \\
\end{array}$ & $\begin{array}{c}\text { Group II } \\
(\mathbf{n}=78)\end{array}$ & P Value \\
\hline Ejection Fraction, \% & $42.66 \pm 8.23$ & $57.92 \pm 7.31$ & 0.023 \\
\hline LVMI, $g / \mathrm{m}^{2}$ & $118.73 \pm 13.57$ & $\begin{array}{c}92.76 \pm \\
8.34\end{array}$ & $<0.001$ \\
\hline $\begin{array}{l}\text { Interventricular Septal } \\
\text { Thickness, cm }\end{array}$ & $1.58 \pm 0.43$ & $0.78 \pm 0.38$ & 0.007 \\
\hline LVEDD, $\mathrm{cm}$ & $6.77 \pm 0.85$ & $4.53 \pm 0.72$ & 0.031 \\
\hline LVESD, cm & $5.21 \pm 0.52$ & $3.21 \pm 0.44$ & 0.012 \\
\hline
\end{tabular}

Table 3. Correlation Between Plasma B2M Level and Selected Clinical, Biochemical, and Echocardiographic Data in Patients With CKD ${ }^{\mathrm{a}}$

\begin{tabular}{|c|c|c|}
\hline Parameter & Correlation $(\mathbf{r})$ & P Value \\
\hline Age, $y$ & -0.081 & 0.431 \\
\hline BMI, $\mathrm{kg} / \mathrm{m}^{2}$ & -0.116 & 0.225 \\
\hline Serum Cr, $\mu \mathrm{mol} / \mathrm{L}$ & 0.536 & $<0.001$ \\
\hline GFR, $\mathrm{mL} / \mathrm{min}$ & -0.033 & $<0.001$ \\
\hline Albumin, $\mathbf{g} / \mathbf{L}$ & -0.521 & $<0.001$ \\
\hline CRP, nmol/dL & 0.167 & $<0.001$ \\
\hline Hemoglobin, g/L & -0.748 & $<0.001$ \\
\hline Calcium, $\mathrm{mmol} / \mathrm{L}$ & -0.223 & 0.067 \\
\hline Phosphate, mmol/L & 0.112 & $<0.001$ \\
\hline Total cholesterol, mmol/L & 0.351 & 0.321 \\
\hline LDL-cholesterol, mmol/L & 0.165 & 0.137 \\
\hline Triglycerides, mmol/L & 0.215 & 0.209 \\
\hline Ejection fraction, \% & -0.625 & $<0.001$ \\
\hline LVMI, $\mathbf{g} / \mathrm{m}^{2}$ & 0.438 & $<0.001$ \\
\hline $\begin{array}{l}\text { Interventricular septal thick- } \\
\text { ness, cm }\end{array}$ & 0.321 & 0.002 \\
\hline LVEDD, cm & 0.275 & 0.006 \\
\hline LVESD, cm & 0.155 & 0.023 \\
\hline
\end{tabular}

a Abbreviations: BMI, body mass index; $\mathrm{Cr}$, creatinine; GFR, glomerular filtration rate; CRP, C-reactive protein; LDL, low-density lipoprotein; LVMI, left ventricular mass index; LVEDD, left ventricular end-diastolic diameter; and LVESD, left ventricular end-systolic diameter.

\section{Discussion}

Our study showed that plasma B2M level was elevated in patients with CKD and this level progressively increased with decreasing GFR. Moreover, plasma B2M level was associated with some metabolic and cardiac performance factors in predialysis CKD patients. Kidneys eliminate $\mathrm{B} 2 \mathrm{M}$ via glomerular filtration and tubular catabolism and hence, plasma level of B2M is highly correlated with GFR (3). Several studies have shown a significant correlation between plasma B2M level and some metabolic factors such as albumin in patients on $\mathrm{HD}$ (15). In addition, B2M is a main predictor of mortality in these patients, independent of other comorbidities such as diabetes, malnutrition, chronic inflammation, and HD duration (15). Liabeuf et al. reported plasma B2M level to be a predictor of overall and cardiovascular mortality and cardiovascular events in patients with different stages of CKD (16). Furthermore, Amighi et al. showed a strong association between serum B2M level and cardiovascular events in patients with prevalent asymptomatic carotid atherosclerosis, with comorbidity severity similar to patients with CKD, even after adjustment for CRP and GFR (17). Cheung et al. reported serum B2M level as a novel risk marker for all-cause and cardiovascular mortality in patients with diabetes mellitus, regardless of renal function (18). Shinkai et al. suggested that in old age population, the predictive value of plasma B2M level was superior to other established prognostic factors for mortality such as GFR, cystatin C, and CRP (19).

Wilson et al. identified that B2M is the most relevant biomarker in screening for peripheral artery disease, probably due to amyloid formation in the vascular wall (10). on the other hand, in another study, B2M was identified as a marker for nutritional status and its serum level was associated with better survival in patients on chronic HD (11).

The role of B2M in patients with CKD is unclear. Uremic milieu has a harmful effect on the cardiovascular system. In an in vitro study, high serum B2M and indole3-acetic acid levels were with low CD34+ and CD133+ endothelial progenitor cells that contribute to vessel repair and neovascularization (20). Moreover, other uremic toxins such as P-cresyl sulfate and guanidine compounds might disturb endothelial proliferation and vascular repair mechanisms $(21,22)$.

Finally, our study had some limitations. First, we did not evaluate correlation between plasma B2M level and arterial stiffness while other studies have demonstrated this association in patients without CKD $(23,24)$. Second, this study had a single-center design with relatively small sample size and therefore, other multicenter studies with large number of participants are required to evaluate the role of $\mathrm{B} 2 \mathrm{M}$ in cardiac performance in patients with CKD.

In conclusion, the results of our study showed that plasma B2M level was significantly and directly correlated with some cardiac performance factors such as LVMI, LVEDD, and LVESD. It was also significantly and inversely associated with GFR, albumin, $\mathrm{Hb}$, and ejection fraction. Thus, B2M might have an important role in the development of cardiovascular diseases in patients with CKD.

\section{Acknowledgements}

We thank Tooba Clinic officers for their cooperation in this study. 


\section{Authors' Contributions}

Omid Sedighi: chief Manager; Saeid Abediankenari: laboratory tests consultant; and Batoul Omranifar: cardiology consultant and data collector.

\section{Funding/Support}

This study was financially supported by Mazandaran University of Medical Sciences, Sari, Iran.

\section{References}

1. Winchester JF, Salsberg JA, Levin NW. Beta-2 microglobulin in ESRD: an in-depth review. Adv Ren Replace Ther. 2003;10(4):279309.

2. Chitra P, Bakthavatsalam B, Palvannan T. Beta-2 microglobulin as an immunological marker to assess the progression of human immunodeficiency virus infected patients on highly active antiretroviral therapy. Clin Chim Acta. 2011;412(11-12):1151-4.

3. Drueke TB, Massy ZA. Beta2-microglobulin. Semin Dial. 2009;22(4):378-80.

4. Fry AC, Singh DK, Chandna SM, Farrington K. Relative importance of residual renal function and convection in determining beta-2-microglobulin levels in high-flux haemodialysis and online haemodiafiltration. Blood Purif. 2007;25(3):295-302.

5. Cheung AK, Rocco MV, Yan G, Leypoldt JK, Levin NW, Greene T, et al. Serum beta-2 microglobulin levels predict mortality in dialysis patients: results of the HEMO study. J Am Soc Nephrol. 2006;17(2):546-55.

6. Locatelli F, Gauly A, Czekalski S, Hannedouche T, Jacobson $\mathrm{SH}$ Loureiro A, et al. The MPO Study: just a European HEMO Study or something very different? Blood Purif. 2008;26(1):100-4.

7. Kazama JJ, Maruyama H, Gejyo F. Reduction of circulating beta2microglobulin level for the treatment of dialysis-related amyloidosis. Nephrol Dial Transplant. 2001;16 Suppl 4:31-5.

8. Vanholder R, Massy Z, Argiles A, Spasovski G, Verbeke F, Lameire $\mathrm{N}$, et al. Chronic kidney disease as cause of cardiovascular morbidity and mortality. Nephrol Dial Transplant. 2005;20(6):1048-56.

9. Menaa C, Esser E, Sprague SM. Beta2-microglobulin stimulates osteoclast formation. Kidney Int. 2008;73(11):1275-81.

10. Wilson AM, Kimura E, Harada RK, Nair N, Narasimhan B, Meng $\mathrm{XY}$, et al. Beta2-microglobulin as a biomarker in peripheral arterial disease: proteomic profiling and clinical studies. Circulation. 2007;116(12):1396-403.

11. Kim KM, Kim SS, Kim H, Koo T, Im EY, Kim SB. Higher serum beta2-microglobulin levels are associated with better survival in chronic hemodialysis patients: a reverse epidemiology. Clin Nephrol. 2011;75(5):458-65.
12. de Simone G, Daniels SR, Devereux RB, Meyer RA, Roman MJ, de Divitiis $\mathrm{O}$, et al. Left ventricular mass and body size in normotensive children and adults: assessment of allometric relations and impact of overweight. J Am Coll Cardiol. 1992;20(5):1251-60.

13. Anderson B. Echocardiography: The Normal Examination and Echocardiographic Measurements.: MGA Graphics;2006.

14. Lang RM, Bierig M, Devereux RB, Flachskampf FA, Foster E, Pellikka PA, et al. Recommendations for chamber quantification: a report from the American Society of Echocardiography's Guidelines and Standards Committee and the Chamber Quantification Writing Group, developed in conjunction with the European Association of Echocardiography, a branch of the European Society of Cardiology. J Am Soc Echocardiogr. 2005;18(12):1440-63.

15. Okuno S, Ishimura E, Kohno K, Fujino-Katoh Y, Maeno Y, Yamakawa T, et al. Serum beta2-microglobulin level is a significant predictor of mortality in maintenance haemodialysis patients. Nephrol Dial Transplant. 2009;24(2):571-7.

16. Liabeuf S, Lenglet A, Desjardins L, Neirynck N, Glorieux G, Lemke $\mathrm{HD}$, et al. Plasma beta-2 microglobulin is associated with cardiovascular disease in uremic patients. Kidney Int. 2012;82(12):1297303.

17. Amighi J, Hoke M, Mlekusch W, Schlager O, Exner M, Haumer M, et al. Beta 2 microglobulin and the risk for cardiovascular events in patients with asymptomatic carotid atherosclerosis. Stroke. 2011;42(7):1826-33.

18. Cheung CL, Lam KS, Cheung BM. Serum beta-2 microglobulin predicts mortality in people with diabetes. Eur J Endocrinol. 2013;169(1):1-7.

19. Shinkai S, Chaves PH, Fujiwara Y, Watanabe S, Shibata H, Yoshida $\mathrm{H}$, et al. Beta2-microglobulin for risk stratification of total mortality in the elderly population: comparison with cystatin $\mathrm{C}$ and C-reactive protein. Arch Intern Med. 2008;168(2):200-6.

20. Jourde-Chiche N, Dou L, Sabatier F, Calaf R, Cerini C, Robert S, et al. Levels of circulating endothelial progenitor cells are related to uremic toxins and vascular injury in hemodialysis patients. $J$ Thromb Haemost. 2009;7(9):1576-84.

21. Schepers E, Glorieux G, Dou L, Cerini C, Gayrard N, Louvet L, et al. Guanidino compounds as cause of cardiovascular damage in chronic kidney disease: an in vitro evaluation. Blood Purif. 2010;30(4):277-87.

22. Meijers BK, Van Kerckhoven S, Verbeke K, Dehaen W, Vanrenterghem Y, Hoylaerts MF, et al. The uremic retention solute p-cresyl sulfate and markers of endothelial damage. Am J Kidney Dis. 2009;54(5):891-901.

23. Saijo Y, Utsugi M, Yoshioka E, Horikawa N, Sato T, Gong Y, et al Relationship of beta2-microglobulin to arterial stiffness in Japanese subjects. Hypertens Res. 2005;28(6):505-11.

24. Kals J, Zagura M, Serg M, Kampus P, Zilmer K, Unt E, et al. beta2microglobulin, a novel biomarker of peripheral arterial disease, independently predicts aortic stiffness in these patients. Scand J Clin Lab Invest. 2011;71(4):257-63. 